\title{
Seasonal Dynamics of Ciliate Cysts and the Impact of Short-Term Change of Salinity in a Eutrophic Coastal Marine Ecosystem
}

\author{
Chien-Fu Chao ${ }^{1}$, An-Yi Tsai $^{2}$, Akira Ishikawa $^{3}$, and Kuo-Ping Chiang ${ }^{1,2,4, *}$ \\ ${ }^{1}$ Department of Environmental Biology and Fisheries Science, National Taiwan Ocean University, Keelung, Taiwan, ROC \\ ${ }^{2}$ Institute of Marine Environmental Chemistry and Ecology, National Taiwan Ocean University, Keelung, Taiwan, ROC \\ ${ }^{3}$ Graduate School of Bioresources, Mie University, Tsu Mie, Japan \\ ${ }^{4}$ Center of Excellence for Marine Bioenvironment and Biotechnology
}

Received 6 March 2013, accepted 18 July 2013

\begin{abstract}
This study investigated the seasonal dynamics of planktonic ciliates, including their cyst production, in a eutrophic coastal ecosystem in the subtropical western Pacific from March 2008 to July 2009. The abundance of planktonic ciliates

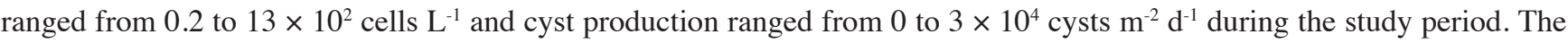
dominant cyst types in this study were Type I and Type II which are similar to Strombidium conicum and Strombidium capitatum, respectively. Cyst abundance changed with inter-day variations in salinity during the warm season $\left(>24^{\circ} \mathrm{C}\right)$, leading us to conclude that environmental change in the form of freshwater input contributed greatly to the encystment of ciliate populations and might be the primary factor controlling encystment production.
\end{abstract}

Key words: Ciliate, Encystment, Salinity, Subtropical water

Citation: Chao, C.F., A. Y. Tsai, A. Ishikawa, and K. P. Chiang, 2013: Seasonal dynamics of ciliate cysts and the impact of short-term change of salinity in a eutrophic coastal marine ecosystem. Terr. Atmos. Ocean. Sci., 24, 1051-1061, doi: 10.3319/TAO.2013.07.18.01(Oc)

\section{INTRODUCTION}

In nature, some species, like the akinete of the phylum cyanobacteria, the cyst of dinoflagellates and ciliates, enter a reversible state of reduced metabolic activity or dormancy into a resting stage (Lennom and Jones 2011). In this stage, they have different body structures (ex. A thick cell wall) and can survive for long periods, sometimes embedded in sediments to protect themselves during unfavorable periods. In this stage, they act as seed banks for the maintenance of biodiversity, stabilization of the ecosystem process, and diffusion of population by passive transport (Gutiérrez et al. 2001; Lennom and Jones 2011; Verni and Rosati 2011). Changing bodily form is a costly process, so these organisms developed a sensitive mechanism which remains attuned to signals of environmental changes. Factors such as temperature, salinity, osmotic pressure, light, $\mathrm{pH}$, and resource (ex. food) directly affect the growth or dormancy of such an organism (Gutiérrez et al. 2001; Lennom and Jones 2011; Verni and Rosati 2011).

\footnotetext{
* Corresponding author

E-mail:kpchiang@mail.ntou.edu.tw
}

There are two hypotheses regarding the function of cysts in ciliates. One hypothesis is that cysts insulate ciliates from low temperatures and help them survive unfavorable conditions with low food availability. This has been called the "overwinter stage" (Reid and John 1978; Müller 1996; Müller and Wünsch 1999). The other hypothesis is that cysts are formed when conditions are favorable to growth and help defend against ingestion by predators, which can be referred to the "defense stage" (Reid 1987). Field studies have noted clear seasonality in cyst formation (Müller et al. 2002). Ciliates as well as their cysts have been described to be in "overwintering stages" when they form in late summer or autumn and in "defense stages" when they form in spring (Müller et al. 2002). Müller and Wünsch (1999) and Müller et al. (2002) found an abundance of cysts increases significantly with decreases in temperature and increases in grazing pressure on the ciliate community.

According to Montagnes et al. 2002, abundances of ciliate population are often governed by ciliate cyclic behavior in response to short-term cyclic variation in environmental factors. Studying cyclical behavior of Strombidium oculatum in a coastal tide-pool, these authors found that ciliate 
cyst formation changed with the tides. Other cycles affecting ciliate behavior, such as light, temperature, salinity, and wave action, occur within a short time frame, ranging from hours to days (Montagnes et al. 2002). Laboratory experiments have observed cyst formation to vary with short-time changes in temperatures and food levels (Weisse 2004). Although these studies provide some insight into short-term variation in the abundance of ciliate cysts, our knowledge regarding these variations remains limited. Even less is known about the interaction between environmental factors and ciliate cysts.

The most frequently used cyst collection methods are long term using sediment traps to obtain flux from surface over several weeks or months (Müller 1996; Müller and Wünsch 1999; Kim et al.2008). However, this method is difficult to compare with environment factors directly. In this study, we first used a sediment trap but limited the collected time (24 hours) and increased collection frequency. From that, we can investigate the temporal variation of ciliate cyst production and the effects of relevant physico-chemical and biological factors from various environment conditions. It is also first time an investigation of year-round cyst abundance from a eutrophic coastal ecosystem of the subtropical western Pacific.

\section{MATERIALS AND METHODS}

Our study site was a semi-enclosed port on the north coast of Taiwan (Fig. 1). There is little ship activity at the port because it was built for as a training area for the piloting of man-powered vessels, and only used occasionally in summer. The port is shallow, with a mean depth of $3 \mathrm{~m}$, with relatively insignificant wave effects inside the port and limited water perturbation except, precipitation and terrigenous particle falloff. Local wastewater is a primary cause for eutrophication. Excluding inclement weather (typhoons and winter monsoons), we generally collected samples bimonthly from March 2008 to July 2009, with some additional samples during the summer. The sediment trap consisted of three cylindrical plastic core tubes $(6.8 \mathrm{~cm}$ diameter; $100 \mathrm{~cm}$ length) with honeycomb baffles covering the trap mouths (Santschi et al. 2003; Hung and Gong 2007). To avoid potential effects from sediment re-suspension, the traps were set at least $0.5 \mathrm{~m}$ above the bottom and placed there for $24 \mathrm{~h}$.

Surface water samples of $5 \mathrm{~L}$ were collected at setting and retrieval of the trap and chlorophyll $a$, nutrients, and vegetative ciliates were determined from subsamples of the water samples. Temperature was measured at the site by a mercury thermometer; salinity was checked from a water sample in a $100 \mathrm{ml}$ vial with manually determined salinity by the Autosal (8400B; Guildline Inc., Canada) in a laboratory. In all, we collected 34 pairs $(34 \times 2$ setting and retrieval $)$ of samples, but lost five salinity samples at the beginning of our study. Water samples were collected by bucket and transported to the laboratory within 20 min after collection for further analysis. The size fractionation of chlorophyll $a$ was determined by passing through 10,2 $\mu \mathrm{m}$ (Nuclepore) and $\mathrm{GF} / \mathrm{F}$ filters and measured with an in vitro fluorometer after extraction with $90 \%$ acetone (Gong et al. 1993, 2000). Nutrient concentrations were measured with a custom-made flow injection analyzer with nitrate $\left(\mathrm{NO}_{3}\right)$ and phosphate $\left(\mathrm{PO}_{4}\right)$ detection limits of 0.3 and $0.03 \mu \mathrm{M}$, respectively (Gong et al. 1995). The water samples for ciliates were subsequently fixed in neutralized formalin ( $2 \%$ final concentration of $\mathrm{v} / \mathrm{v})$, and $100 \mathrm{ml}$ water samples were concentrated using the

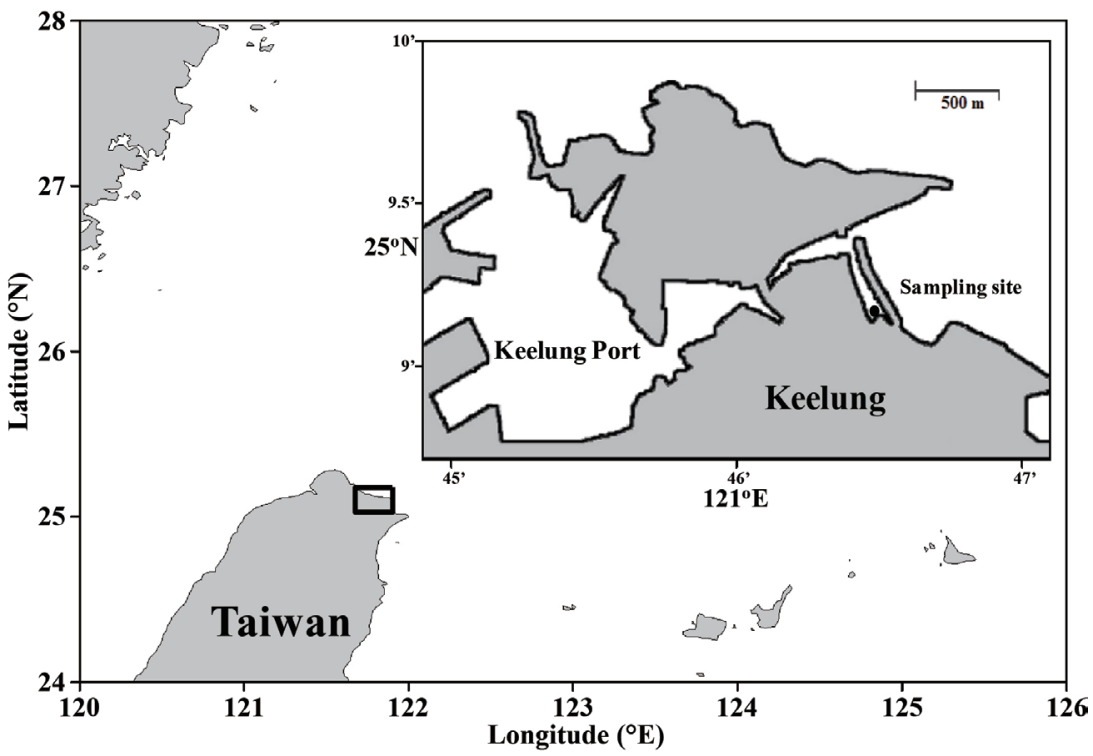

Fig. 1. Location of sampling sites in the coastal waters of the western subtropical Pacific, Keelung, north coast of Taiwan. 
Utermöhl method (Hasle 1978). The ciliates in each sample were carefully counted using an inverted epifluorescence microscope (Nikon-Tmd 300) at 200× or 400× magnifications. Based on cell shape, lorica and collar appearance, the ciliates were categorized into Strombidium spp., Strobilidium spp., Mesodinium spp., and tintinnids.

After retrieval of the trap, the collected samples were sieved through a $200 \mu \mathrm{m}$ mesh. The trapped particles were concentrated to $20 \mathrm{ml}$ and sonicated with an ultrasonic cleaner (Branson 2510; $40 \mathrm{kHz}$ ) for 10 - $30 \mathrm{~s}$. The sonicated sediment particles were sequentially sieved through 100 and $20 \mu \mathrm{m}$ screens. The sediment particles, which were retained on the $20 \mu \mathrm{m}$ screen, were washed and found cysts with size ranges from 20 to $100 \mu \mathrm{m}$. Only $3.8 \%$ of the total cysts were lost, leaving a sample with a reasonable number of cysts to study (Ichinomiya et al. 2004). The processed sediment particles were examined in a Sedgewick Rafter chamber after being fixed with glutaraldehyde (2.5\% final concentration) under an epifluorescence microscope at a magnification of 200x. The cell walls of cysts were recognized by their yellow-green fluorescence under blue excitation light, and cyst types were identified following the description of Kim (1995), Kim and Taniguchi (1995), Kim et al. (2002), Ichinomiya et al. (2004), Agatha et al. (2005), and Kim et al. (2008).

To understand the impact of short-term environmental change on ciliate encystment, we compared the inter-day variation in environmental factors, including temperature, salinity, chlorophyll $a$, and vegetative ciliates with the number of cysts we collected. The indicator of inter-day variation is the average, difference, and coefficient of variation (CV) of these environmental factors between the time the trap was set and the time it was retrieved 24 hours later. All statistical operations, including correlation analysis, regression analysis, and T-test, were performed using SPSS (version 13).

\section{RESULTS}

\subsection{Environmental Conditions and Chlorophyll $a$ Con- centrations}

During the 17-month observation period (March 2008 to July 2009) water temperatures ranged between $17^{\circ} \mathrm{C}$ (January) and $31^{\circ} \mathrm{C}$ (July) and exhibited a clear two-phase seasonal cycle. The warm season $\left(>24^{\circ} \mathrm{C}\right)$ was from May to October and the cold season $\left(<24^{\circ} \mathrm{C}\right)$ from November to April (Fig. 2). There was no clear seasonal variation in salinity (Fig. 2), though there was wide day-to-day variation in salinity in January 2009, but for instance a wide day-to-day variation due to fresh water input caused acute daily change in January 2009 ( 31 on the $15^{\text {th }}$ of January, and 9 on the $16^{\text {th }}$ of January, Fig. 2). On the other hand salinity may increase slowly because of evaporation due to high temperature or mixing with incoming outside sea water. It happened only three times when the daily increase in salinity was greater than 5 (22.7 to $28.4,11.9$ to 19.7 , and 9.8 to 17.2 respectively on $22^{\text {th }}$ to $23^{\text {th }}$ of May, $5^{\text {th }}$ to $6^{\text {th }}$ of Jun 2008 , and $31^{\text {th }}$ of March to $1^{\text {th }}$ of April 2009). In general, the study site was a eutrophic subtropical coastal ecosystem, nitrate ranged from 1.12 to $1.43 \times 10^{2} \mu \mathrm{M}$, with an average of $28.9 \mu \mathrm{M}$ The average concentrations of $\mathrm{NO}_{3}{ }^{-}$and $\mathrm{PO}_{4}^{-}$were 1.78 and $1.55 \mu \mathrm{M}$. We found an inverse relationship between regression of salinity and nitrate $(p<0.01)$, suggesting influence due to wastewater input.

Chlorophyll $a$ concentrations varied between 0.03 and $6.45 \mathrm{mg} \mathrm{m}^{-3}$ (average $2.29 \mathrm{mg} \mathrm{m}^{-3}$ ), with higher concentrations

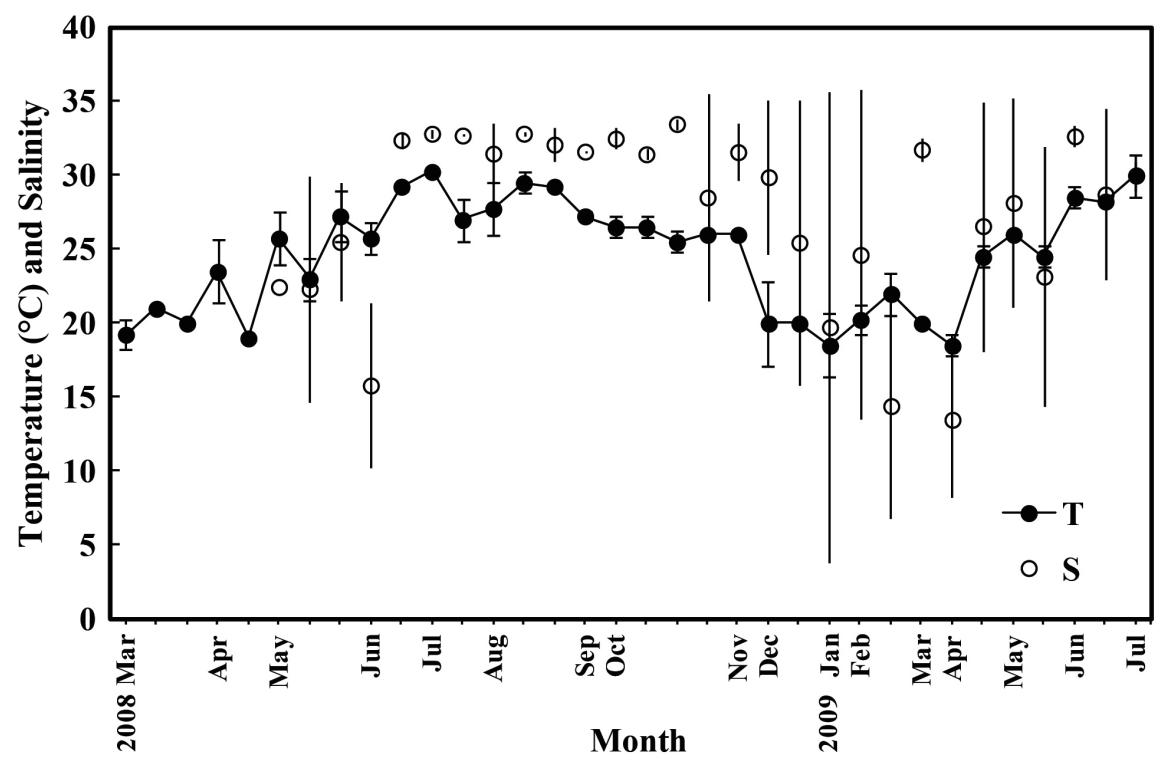

Fig. 2. Temporal variations in inter-day average of surface water temperature and salinity between setting and retrieval of the trap, from March 2008 to July 2009. Ticks labeled with a month on the x-axis indicate the first sampling date of that month. Unlabeled ticks indicate subsequent sampling date of the same month in $\mathrm{X}$-axis. Error bars are $\pm \mathrm{SD}$. 
found during the warm season (Fig. 3). However, values of $>$ $1 \mathrm{mg} \mathrm{m}^{-3}$ were occasionally recorded during the cold season (Fig. 3). Chlorophyll $a$ was divided into 3 size classes $(<2$, $2-10$ and $>10 \mu \mathrm{m})$. The dominant group was $>10 \mu \mathrm{m}$ and made up an average of $56.7 \%$ of the total chlorophyll $a$ concentrations in the warm season (Fig. 3).

\subsection{Seasonal Patterns of Vegetative Ciliates}

Vegetative ciliate densities varied from 0.2 to $13 \times 10^{2}$ cells $\mathrm{L}^{-1}$ throughout our study period. Generally the highest abundance of ciliates was during the warm season (Fig. 4); a regression relationship between ciliate abundance and temperature was present (Fig. 5). During the study period, Mesodinium spp., Strombidium spp., Strobilidium spp., and tintinnids, respectively, contributed on average 34.2, $28,27.6$ and $10.2 \%$ of the total ciliate abundance (Fig. 4).

\subsection{Dynamics of Cyst Production}

Based on the characteristics of the cysts, we categorized them into seven types, Type I: a flask-shaped cyst, known as

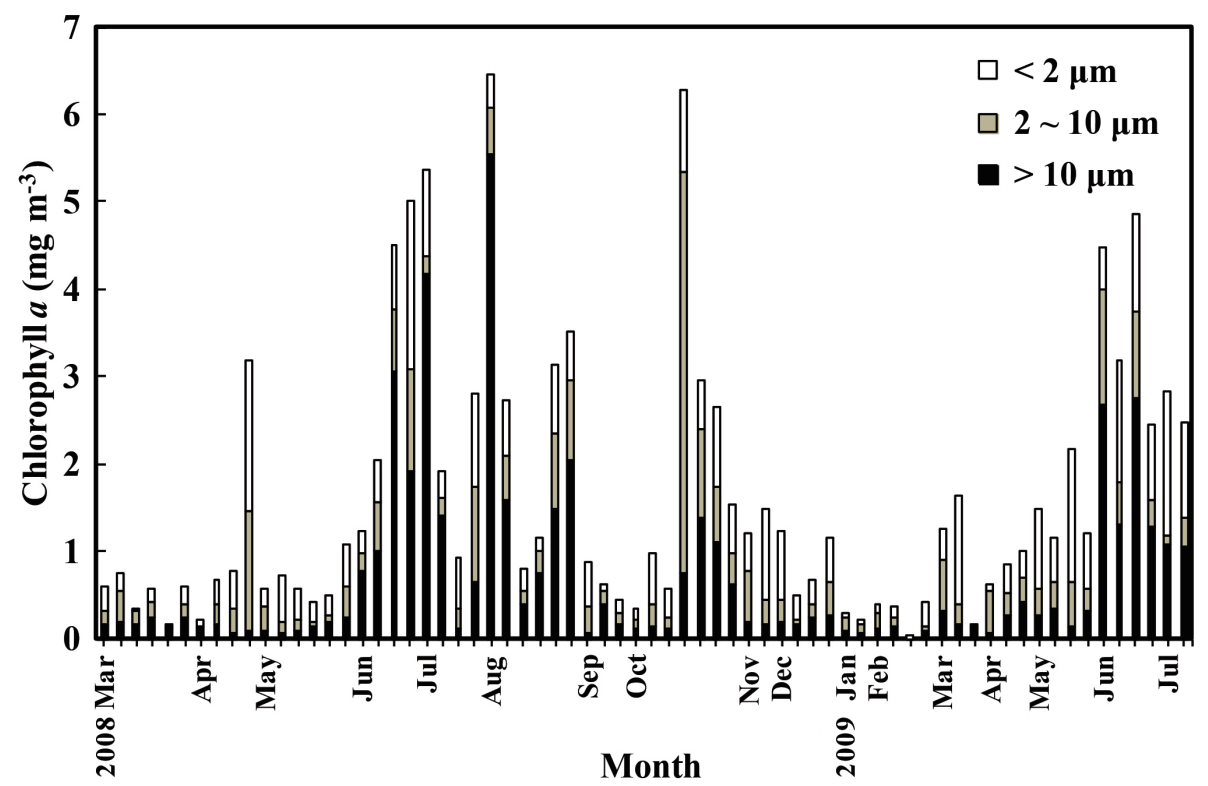

Fig. 3. Temporal variations in chlorophyll $a$ concentrations of three size classes during the study period. See Fig. 2 for an explanation of x-axis labels.

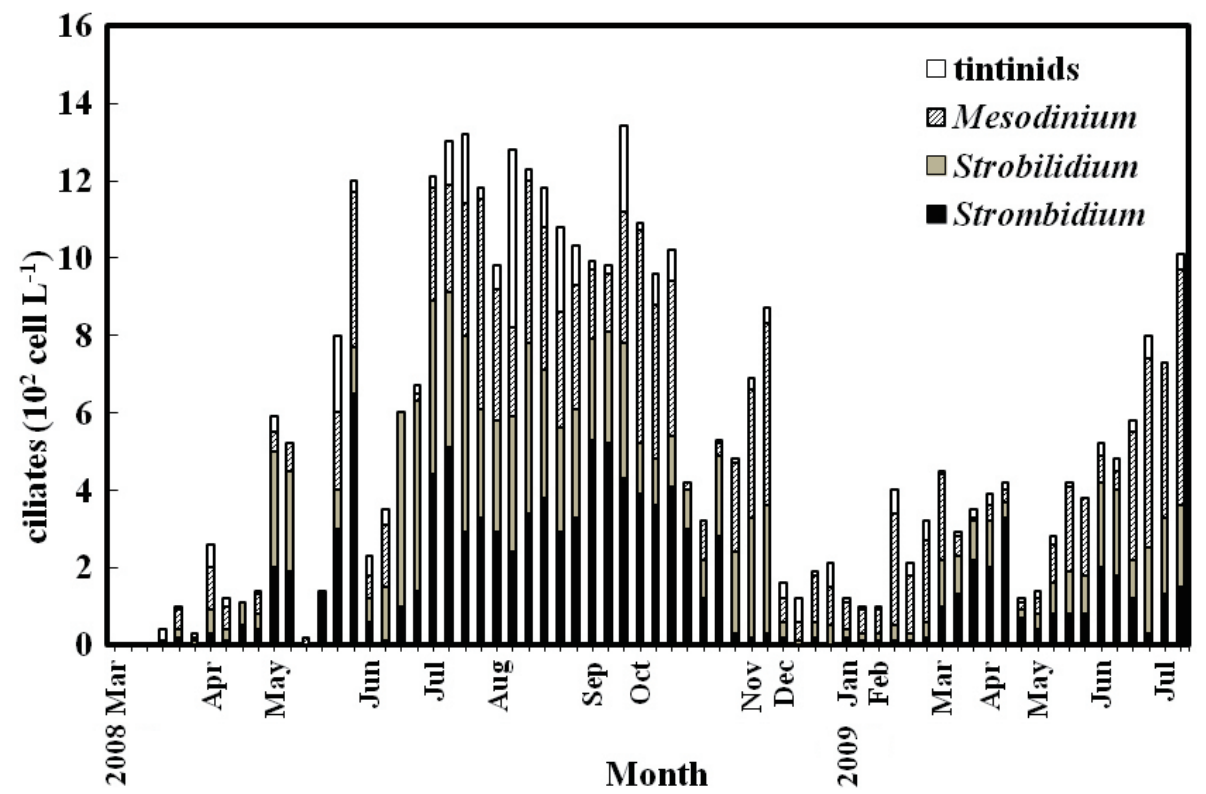

Fig. 4. Temporal variations in ciliate abundance (cells $\mathrm{L}^{-1}$ ). See Fig. 2 for an explanation of $\mathrm{x}$-axis labels. 


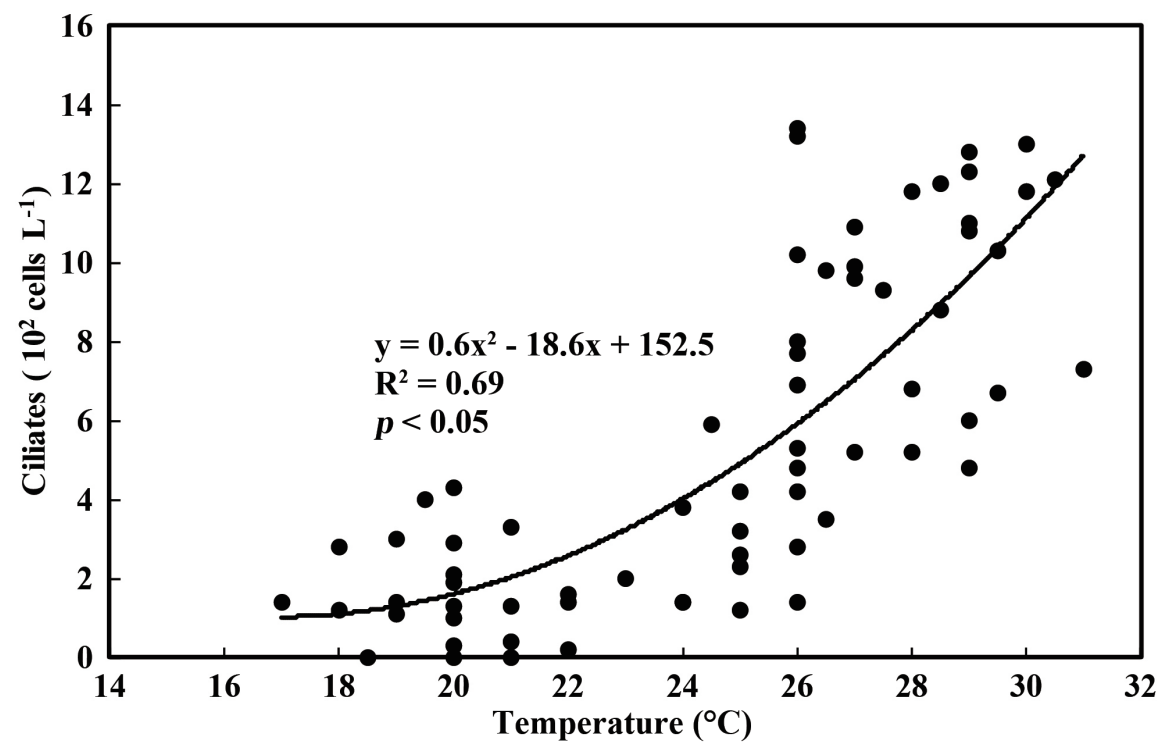

Fig. 5. Relationship between temperature and ciliate abundance (cells $\mathrm{L}^{-1}$ ) during the study period.

"papuliferes" (Figs. 6a, b) and similar to Strombidium conicum (Reid and John 1978; Kim and Taniguchi 1995); Type II: a spherical cyst, nearly spherical with a short collar and spines on the surface (Figs. 6c, d) similar to the Strombidium capitatum cyst (Kim et al. 2008); Type III: an oval cyst, with an oval main body and a long tail (Figs. 6e, f) similar to Cyrtostrombidium boreale (Kim et al. 2002); Type IV: a squared cyst, with a long tail but squared shape (Figs. 6g, h) similar to Strombidium cornucopiae (Kim 1995); Type V: a slender flask cyst, a flask-shaped cell with more slender form like a bowling pin and with spines on the surface similar to Strombidium biarmatum (Figs. 6i, j) (Agatha et al. 2005); and, the Tintinnid cyst, categorized as Type VI, is counted only when the lorica was clean enough and the cyst inside could be recognized. (Figs. 6k, 1). Other cysts with a papula but covered by impurities or unidentifiable were categorized as "unknown" (Figs. 6m, n).

The abundance of cysts ranged between 0 and $3 \times 10^{4}$ cysts $\mathrm{m}^{-2} \mathrm{~d}^{-1}$ (Fig. 7) and without significant seasonal pattern. A high abundance of cysts was recorded in both warm (June 2008 and June 2009) and cold seasons (February to May). Type I and Type II cysts were dominant types, with abundances varying from 0 to $1.8 \times 10^{4}$ and 0 to $2.4 \times 10^{4}$ cysts $\mathrm{m}^{-2} \mathrm{~d}^{-1}$, respectively. On average, they made up 62 and $17 \%$ of the total cyst production (Fig. 7). It is worth noting that cyst formation was negatively correlated with vegetative ciliate abundance $(p<0.05)$ during the warm season $\left(>24^{\circ} \mathrm{C}\right)$. There was no relationship observed during the cold season $\left(<24^{\circ} \mathrm{C}\right)$. However, if the unusual high cyst production which occurred on Mar 20, 2008 was excluded from our analysis, we found a strong positive correlation between cyst production and vegetative ciliate abundance ( $p=0.001)$ (Fig. 8).

Cyst production was significantly related to variations in salinity $\left(\mathrm{CV}\right.$ of salinity) during the warm season $\left(>24^{\circ} \mathrm{C}\right)$ but not during the cold season $\left(<24^{\circ} \mathrm{C}\right)$ (Fig. 9). Furthermore, the various types of cyst abundance also showed a significant relationship between inter-day average of salinity, inter-day average of Strombidium spp. during the warm season (Table 1).

\section{DISCUSSION}

\subsection{Seasonal Variation in Abundance of Vegetative Ciliates}

There was a clear seasonal pattern in the abundance of vegetative ciliates in this eutrophic subtropical coastal ecosystem which resulted from the influence of physical and biological factors. Higher abundances were often recorded during the summer period suggesting distinct seasonal trends seemingly related to temperature (Fig. 5). Similar seasonal trends have also been reported by studies of other environments (Andersen and Soresen 1986; Leakey et al. 1992; Chiang et al. 2003). However, temperature may not directly cause seasonal changes in ciliate abundance. It may also be affected by food supply and predators in the summer periods (Nielsen and Kiorboe 1994; James and Hall 1995; Suzuki et al. 1998). One previous study of coastal water (Sherr et al. 1989) suggested that a presence of $10^{6}$ cells $\mathrm{ml}^{-1}$ of bacteria might be sufficient to allow ciliates $<15 \mu \mathrm{m}$ to grow at a doubling rate per $48 \mathrm{~h}$. In a preliminary study, we found bacterial and nanoflagellate abundance to be about $10^{6}$ and $3 \times 10^{3}$ cells $\mathrm{ml}^{-1}$, respectively, in the cold season $\left(<24^{\circ} \mathrm{C}\right)$. Bacteria and nanoflagellates, both food sources for ciliates, were sufficiently abundant throughout the study period. Chlorophyll $a$ may be an indirect indicator for food resource. We found occasionally high concentrations of 


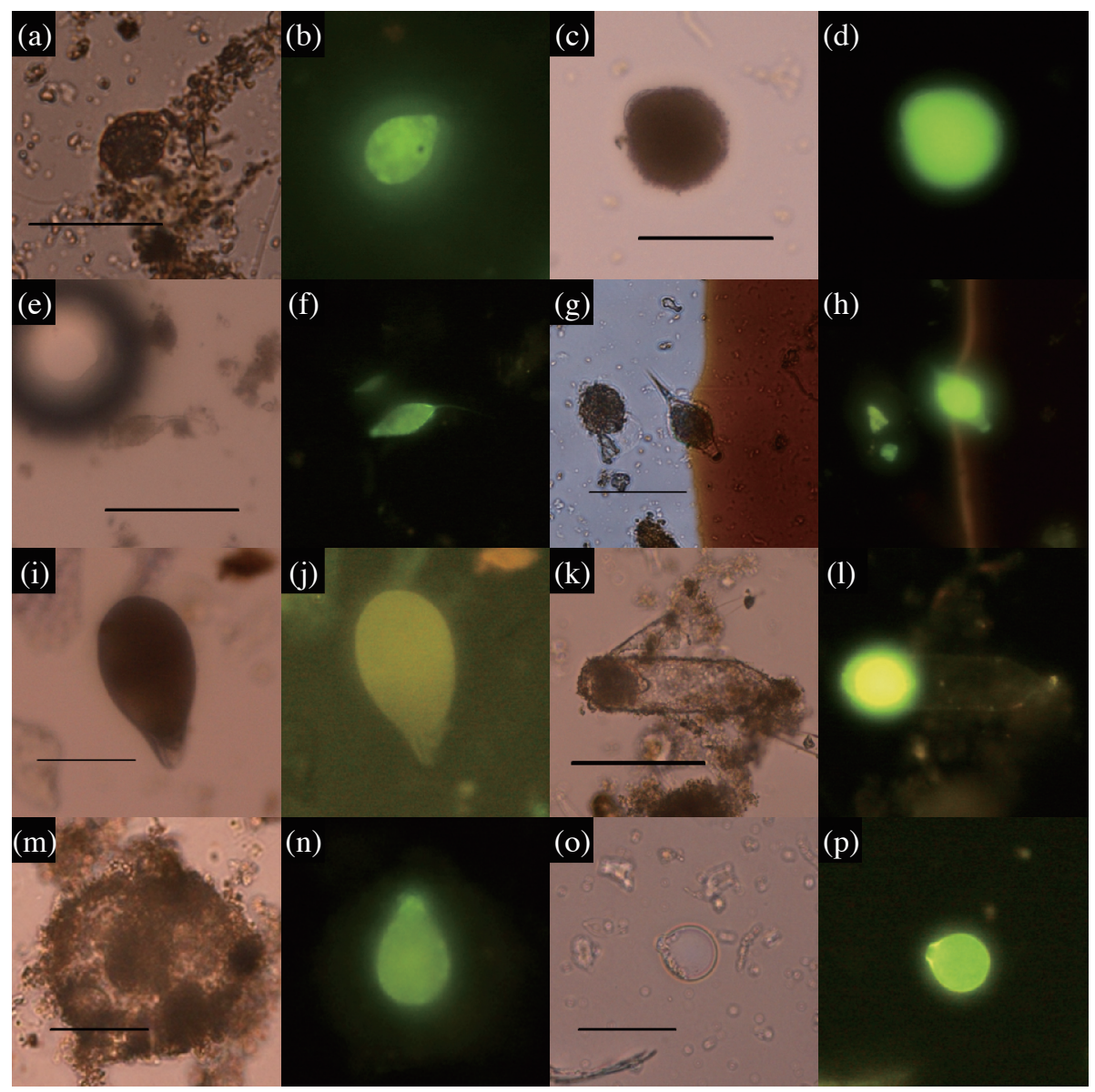

Fig. 6. Microphotographs under regular light (a, c, e, g, i, k, m, o) and epifluorescence light (b, d, f, h, j, l, n, p). A and b: Type I, the flask-shaped cyst; c and d: Type II, the spherical cyst; e and f: Type III, the oval cyst; $g$ and h: Type IV, the squared cyst; i and j: Type V, the slender flask cyst; $\mathrm{k}$ and $\mathrm{l}$; Type VI, tintinnids; $\mathrm{m}$ and $\mathrm{n}$; an unknown cyst among sediment particles; o and $\mathrm{p}$ : an empty cyst. Scale bars $=50 \mu \mathrm{m}$.

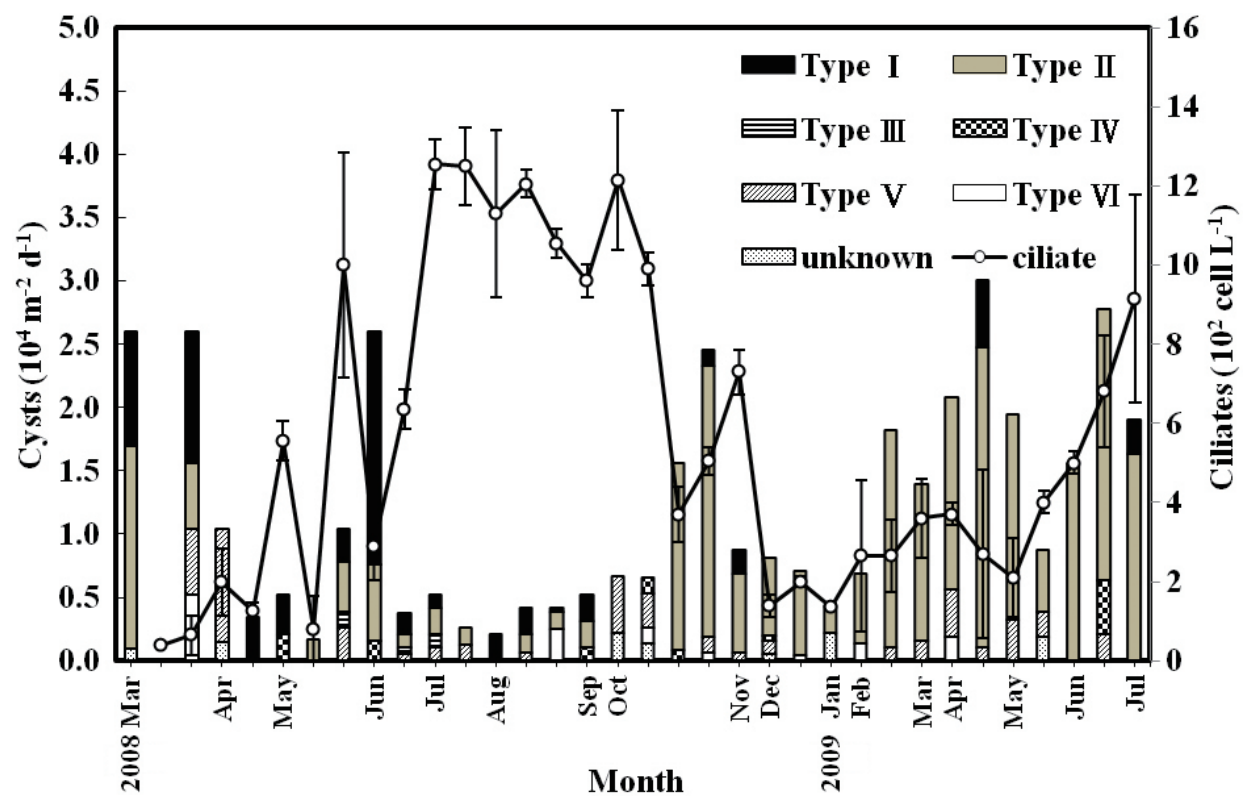

Fig. 7. Temporal variations in inter-day average ciliate abundance (cells $\mathrm{L}^{-1}$ ) between setting and retrieval of the trap, and production of cysts $\left(10^{4} \mathrm{~m}^{-2} \mathrm{~d}^{-1}\right)$. See Fig. 2 for an explanation of $\mathrm{x}$-axis labels. 


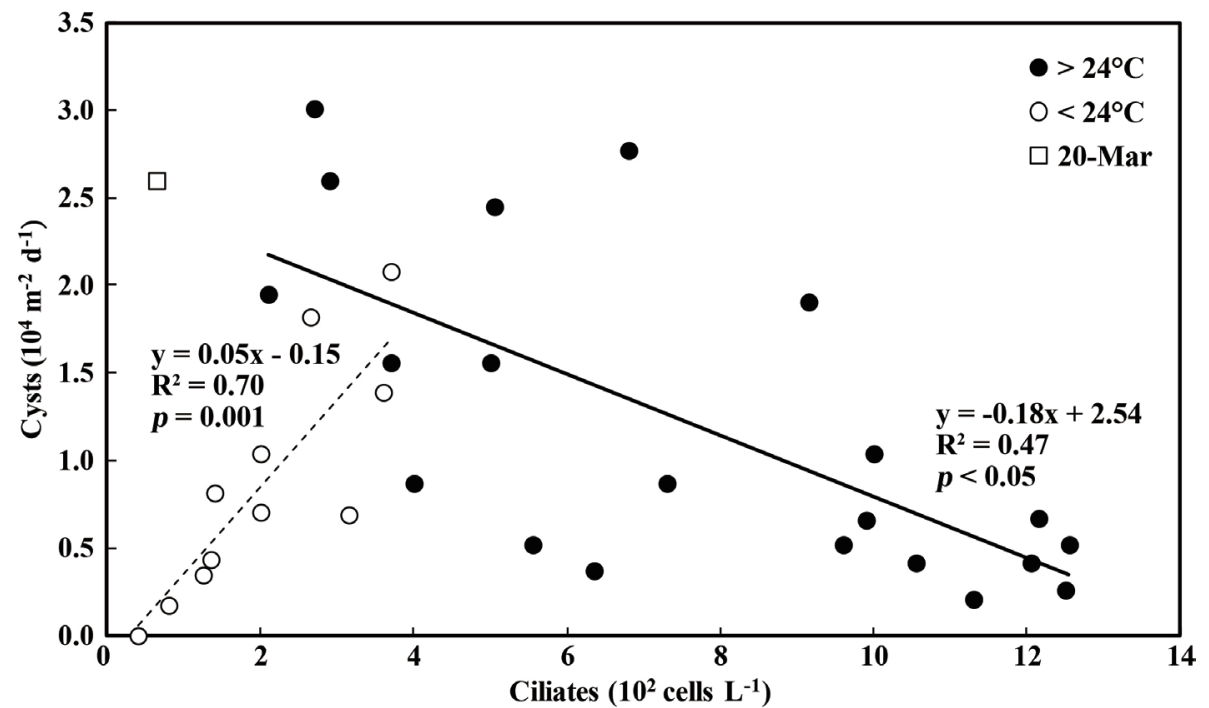

Fig. 8. The relationship between the warm $(\bullet)$ and cold season $(O)$ of cyst production and inter-day average ciliate abundance during the study period.

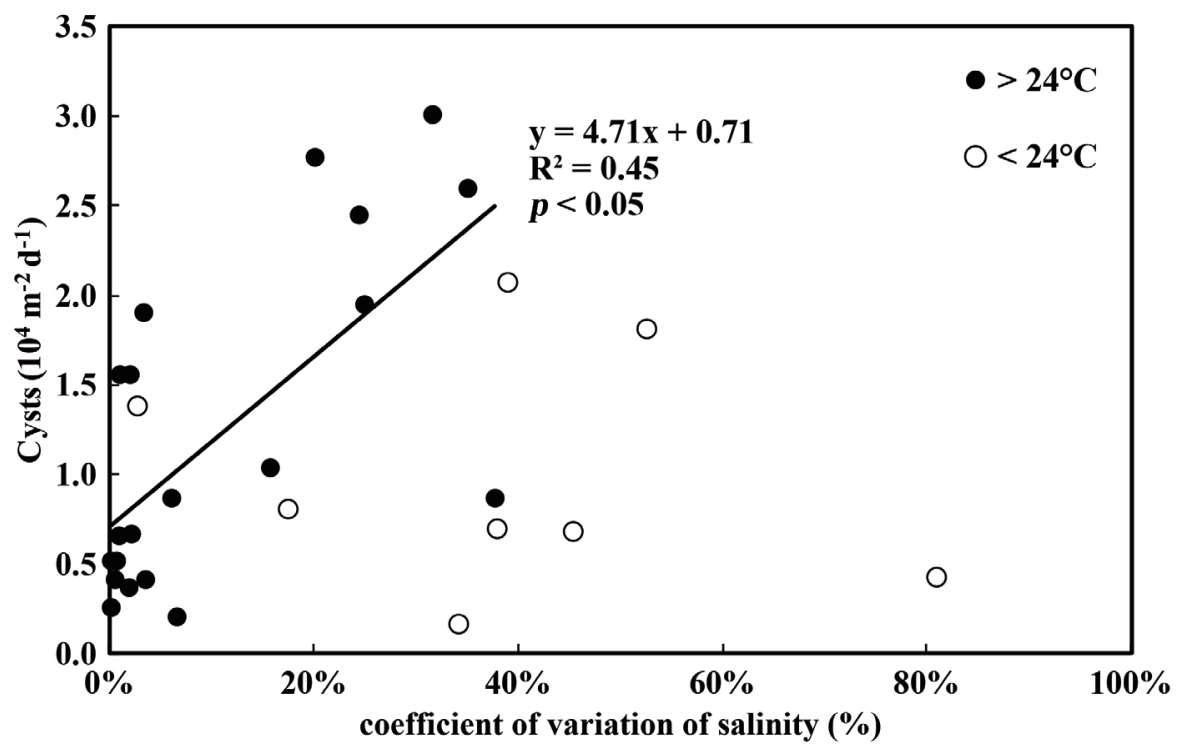

Fig. 9. The relationship between the coefficient of variation (CV) of salinity and cyst production.

Table 1. Correlation coefficient between various types of cyst abundance and inter-day average of salinity, daily average of Strombidium spp. in the warmer seasons $\left(>24^{\circ} \mathrm{C}\right)(* * p<0.01, * p<0.05)$.

\begin{tabular}{|c|cc|}
\hline & inter-day average of salinity & inter-day average of $\boldsymbol{S}$ spp. \\
\hline cyst type & $-\mathbf{0 . 4 4 6} *$ & $\mathbf{- 0 . 6 0 4 * *}$ \\
\hline total cysts & $\mathbf{- 0 . 7 3 9 * *}$ & -0.291 \\
Type I & -0.107 & $\mathbf{- 0 . 5 7 0 * *}$ \\
Type II & -0.01 & $\mathbf{0 . 4 2 2 *}$ \\
Type III & -0.301 & -0.169 \\
Type IV & 0.012 & 0.152 \\
Type V & 0.166 & 0.179 \\
Type VI & -0.036 & 0.114 \\
unknown & & \\
\hline
\end{tabular}


chlorophyll $a$ during the cold season, suggesting no food shortage at that time (Fig. 3). Taken together, these results suggest that temperature might control ciliate growth activity during the colder months (Fig. 5). Furthermore, our finding of large variations in ciliate abundance in the water at temperatures higher than $24^{\circ} \mathrm{C}$ in the warmer seasons suggests that there may be other factors, including predation, that control ciliate abundance. It is well-known, for example, that ciliate populations can be suppressed by metazoan predation (Dolan 1991; Nielsen and Kiorboe 1994; Hadas and Berman 1998).

Loss of cells due to fixation and preservation is a serious problem in the measurement of ciliate abundance. Loss of cells by formaldehyde is up to $20 \%$ when compared with counts of life collection (Dale and Burkill 1982), or samples preserved in Lugol's solution (Stoecker et al. 1989). Pitta et al. (2001) reported no significant difference between samples fixed with formaldehyde and Lugol's solution. Despite of its underrating of ciliate abundance, formaldehyde is still the most common fixative for ciliates (Chiang et al. 2003; Kim et al. 2008; Tsai et al. 2011) because of its advantage in examination of chlorophyll pigments (Stoecker et al. 1994) and keeping the cell volume (Ohman and Snyder 1991; Jerome et al. 1993; Zinabu and Bott 2000). In this study we, therefore, used formaldehyde-based fixative. It may create bias in representing ciliate community structures. We may underrate the ciliate abundance but its seasonal patterns will not change.

\subsection{Cyst Abundance and Environmental Factors}

This study is the first record of cyst formation in a field population of ciliates in a eutrophic coastal ecosystem of subtropical western Pacific. We observed that cysts were formed in both high (June 2008 and June 2009) and low temperature periods (February to May 2009) (Fig. 7), with abundances as high as $>2.5 \times 10^{4}$ cysts $\mathrm{m}^{-2} \mathrm{~d}^{-1}$. Müller et al. (2002) reported the two-peak seasonal dynamics of cyst formation of strombidiid ciliates in Lake Mondsee, one occurring in spring when food was sufficient and another in fall when food supply was low. They reported a maximum value of $2 \times 10^{5}$ cysts $\mathrm{m}^{-2} \mathrm{~d}^{-1}$. The vegetative ciliate abundances we found $\left(0.2\right.$ to $13 \times 10^{2}$ cells $\left.\mathrm{L}^{-1}\right)$ were two orders lower than those reported in their study $\left(2.6 \times 10^{3}\right.$ to $1.3 \times 10^{4}$ cells L $\left.{ }^{-1}\right)$ of Lake Mondsee. As in our study, Müller and Wünsch (1999) and Müller et al. (2002) reported seasonal patterns in cyst formation of ciliates.

Cyst re-suspension and turbulent mixing of the sediment possibly lead to the vertical redistribution of the resting stages in the sediment (Marcus 1984; Kremp and Heiskanen 1999). Problems relating to the sediment trap technique have been discussed in detail by Bloesch and Burns (1980). According to those authors, one factor related to the overestimation of downward settling fluxes is re-suspension of bottom deposits. For dinoflagellates, Kremp (2001) showed that the beginning of the cyst germination period coincided frequently with stormy weather which has a high potential for causing re-suspension. Similarly, Nehring (1996) found an association between dinoflagellate blooming and calm weather and stability of the water column, though role of cyst re-suspension due to sediment reworking and physical re-suspension may be related to the time and recurrence of dinoflagellate blooms. We could not exclude the possibility of overestimates due to re-suspension in the present study. However, because the strength of wind and wave (recorded by the meteorological buoy just outside the harbor, data not shown) was not significantly related with the cyst abundance in this study, we believe that such overestimation, if present, was insignificant.

This study is the first to describe a resting stage in a non-loricate ciliate from a subtropical eutrophic environment. We found a simple relationship between the inter-day average of ciliate abundance and cyst production (Fig. 8), suggesting that ciliates disappear from the planktonic community in the water column in the warm season $\left(>24^{\circ} \mathrm{C}\right)$. Furthermore, the close relationship we found between cyst production and the inter-day variations of salinity (CV of salinity) (Fig. 9) suggests that variations of salinity might excite ciliates to enhance encystment, causing a decrease in vegetative ciliate abundance and an increase in cyst production (Figs. 8, 9). During the warm season, the encystment of ciliate was active following a dramatic change in salinity within a short-period (< several hours) (Fig. 9). This phenomenon was also demonstrated by culture experiment in a laboratory experiment (data not shown).

During the cold season $\left(<24^{\circ} \mathrm{C}\right)$, we often observed high inter-day salinity change and low abundance of vegetative ciliates (Figs. 2, 7). Except for March 20, cyst production was positively related with ciliate abundance but not significantly with salinity (Fig. 9). We believe that vegetative ciliates formed a stable ratio under the serious stimulation induced by an unfavorable condition (high inter-day salinity change), but the abundance of vegetative ciliates was too low to produce a sufficient amount of cysts resulting in an increase in cyst abundance and subsequent increase in vegetative ciliates. For example, a serious inter-day change in salinity between the $15^{\text {th }}$ and $16^{\text {th }}$ of January 2009 (31 to 9, CV 81\%) resulted in the abundance of only $0.44 \times 10^{4}$ cysts $\mathrm{m}^{-2} \mathrm{~d}^{-1}$ (Figs. 2, 8,9). We believe that it is because the vegetative ciliate abundance showed only 130 - $140 \mathrm{~L}^{-1}$. As ciliate abundance reaches nearly to the level during the warm season $\left(>2 \times 10^{2} \mathrm{~L}^{-1}\right)$, the cyst production will increase (Figs. 8, 9); this phenomenon will be demonstrated in the future.

In Müller (1996), cyst formation occurred shortly after food had been reduced to a low abundance by ciliate grazing, Müller and Wünsch (1999) also found a similar pattern during the fall when food was insufficient. While there may be an "overwintering stage" strategy allowing ciliates 
to survive low temperature and short food supply (Müller 1996; Müller and Wünsch 1999), our study found lower cyst formation $\left(1.0 \times 10^{4}\right.$ cysts $\left.\mathrm{m}^{-2} \mathrm{~d}^{-1}\right)$ during the winter period (from November to January) suggesting the possibility for low temperature to cause low cyst formation. Moreover, Reid (1987) and Müller and Wünsch (1999) found that when food availability increased in spring, ciliate population also increased and in the meantime they also found increasing in ciliate encystment. They speculated that the increase in ciliate encystment was due to increasing predation pressure caused by the simultaneously higher abundance of copepods. We also found an increase in ciliate encystment in early spring (February to April) (Fig. 7), though we did not have data to support the cause by copepods predation pressure.

In our study, based on the cyst morphology, Strombidium spp. cysts accounted for almost the entire ciliate cyst community (excluding "tintinnids" and two "unknown" types), and the same has been reported by a number of studies (Ichinomiya et al. 2004; Agatha et al. 2005; Kim et al. 2008; McManus et al. 2010). There is also a significant negative correlation between cyst abundance and inter-day average Strombidium spp. abundance in warm season $\left(>24^{\circ} \mathrm{C}\right)$, $(\mathrm{r}=-0.53, p<0.05)$.

Type II and Type I (which are similar to Strombidium capitatum, and Strombidium conicum, repectively) were the dominant cyst types in this study (Fig. 7). Similarly, Kim and Taniguchi $(1995,1997)$ and Ichinomiya et al. (2004) have reported Strombidium conicum to be the most dominant species of the ciliate community in Onagawa Bay. Kim et al. (2008) also observed a considerable amount of Strombidium capitatum cysts in Onagawa Bay, Japan, and Masan Bay, Korea, where temperatures in colder season fall below $5^{\circ} \mathrm{C}$. Thus, low temperatures could cause the cyst formation in these two bays. In our study, the abundance of Type II and Type I cysts was significantly related to salinity and abundance of vegetative Strombidium spp. in warmer seasons $\left(>24^{\circ} \mathrm{C}\right.$ ), but not during the cold season (Table 1) suggesting both species were strongly sensitive to salinity and cyst formation affected the vegetative abundance immediately.

We did not study excystment and we only identified cyst taxa morphologically. Furthermore, information characterizing cysts is somewhat limited (Agatha et al. 2005; Kim et al. 2008; McManus et al. 2010). Strombidium capitatum is adapted to low and moderate temperatures $\left(13-15^{\circ} \mathrm{C}\right)$ and aestivates during warm summer months (Kim et al. 2008). Its life cycle is different from the same species in our study. Therefore, it is probable that Strombidium capitatum has adapted to a subtropical habitat or the cysts we found were confused with similar cysts produced by other species. Cyst formation in ciliates is a complex phenomenon and encystment processes depend upon a number of environmental factors. To understand the ecology of planktonic ciliates, a quantitative investigation of their cysts in the water column is indispensable. At present it is difficult to identify ciliate cysts because current identification is based mainly on limited information of morphological characteristics. Thus, in addition to germination experiments, in the future molecular biotechnology such as rRNA, DNA, should be a standard process for cyst identification.

Acknowledgments This study was supported by a grant (NSC 95-2611-M-019-022-MY3) from the National Science Council, ROC. We are most grateful to Mr. James Steed and Dr. Chang Tai Shih for the language editing and comments on the manuscript.

\section{REFERENCES}

Agatha, S., M. C. Strüder-Kypke, A. Beran, and D. H. Lynn, 2005: Pelagostrobilidium neptuni (Montagnes and Taylor, 1994) and Strombidium biarmatum nov. spec. (Ciliophora, Oligotrichea): Phylogenetic position inferred from morphology, ontogenesis, and gene sequence data. Eur. J. Protistol., 41, 65-83, doi: 10.1016/j.ejop.2004.09.005. [Link]

Andersen, P. and H. M. Sørensen, 1986: Population dynamics and trophic coupling in pelagic microorganisms in eutrophic coastal waters. Mar. Ecol. Prog. Ser., 33, 99-109.

Bloesch, J. and N. M. Burns, 1980: A critical review of sedimentation trap technique. Schweiz. Z. Hydrol., 42, 1555, doi: 10.1007/BF02502505. [Link]

Chiang, K. P., C. Y. Lin, C. H. Lee, F. K. Shiah, and J. Chang, 2003: The coupling of oligotrich ciliate populations and hydrography in the East China Sea: Spatial and temporal variations. Deep-Sea Res. Part II-Top. Stud. Oceanogr., 50, 1279-1293, doi: 10.1016/S09670645(03)00023-7. [Link]

Dale, T. and P. H. Burkill, 1982: "Living counting": A quick and simple technique for enumerating pelagic ciliates. Ann. Inst. Océanogr., 58, 267-276.

Dolan, J. R., 1991: Guilds of ciliate microzooplankton in the Chesapeake Bay. Estuar. Coast. Shelf Sci., 33, 137152, doi: 10.1016/0272-7714(91)90003-T. [Link]

Gong, G. C., W. R. Yang, and Y. H. Wen, 1993: Correlation of chlorophyll $a$ concentration and Sea Tech fluorometer fluorescence in Seawater. Acta Oceanogr. Taiwan., 31, 117-126.

Gong, G. C., K. K. Liu, and S. C. Pai, 1995: Prediction of nitrate concentration from two end member mixing in the southern East China Sea. Cont. Shelf Res., 15, 827 842, doi: 10.1016/0278-4343(94)00039-P. [Link]

Gong, G. C., F. K. Shiah, K. K. Liu, Y. H. Wen, and M. H. Liang, 2000: Spatial and temporal variation of chlorophyll $a$, primary productivity and chemical hydrography in the southern East China Sea. Cont. Shelf Res., 20, 411-436, doi: 10.1016/S0278-4343(99)00079-5. [Link]

Gutiérrez, J. C., S. Callejas, S. Borniquel, L. Benítez, and A. Martín-González, 2001: Ciliate cryptobiosis: A 
microbial strategy against environmental starvation. Int. Microbiol., 4, 151-157, doi: 10.1007/s10123-0010030-3. [Link]

Hadas, O. and T. Berman, 1998: Seasonal abundance and vertical distribution of Protozoa (flagellates, ciliates) and bacteria in Lake Kinneret, Israel. Aquat. Microb. Ecol., 14, 161-170, doi: 10.3354/ame014161. [Link]

Hasle, G. R., 1978: The inverted microscope. In: Sournia, A. (Ed.), Phytoplankton Manual, Monographs on Oceanographic Methodology, UNESCO, Paris, 88-96.

Hung, C. C. and G. C. Gong, 2007: Export flux of POC in the main stream of the Kuroshio. Geophys. Res. Lett., 34, L18606, doi: 10.1029/2007GL030236. [Link]

Ichinomiya, M., M. Nakamachi, and A. Taniguchi, 2004: A practical method for enumerating cysts of ciliates in natural marine sediments. Aquat. Microb. Ecol., 37, 305-310, doi: 10.3354/ame037305. [Link]

James, M. R. and J. A. Hall, 1995: Planktonic ciliated protozoa: Their distribution and relationship to environmental variables in a marine coastal ecosystem. J. Plankton Res., 17, 659-683, doi: 10.1093/plankt/17.4.659. [Link]

Jerome, C. A., D. J. S. Montagnes, and F. J. R. Taylor, 1993: The effect of the quantitative protargol stain and Lugol's and Bouin's fixatives on cell size: A more accurate estimate of ciliate species biomass. J. Eukaryot. Microbiol., 40, 254-259, doi: 10.1111/j.15507408.1993.tb04913.x. [Link]

Kim, Y. O., 1995: Life cycle strategies of choreotrich ciliate plankton in Onagawa Bay. Ph.D. Thesis, Tohoku University, Sendai, Japan, 173 pp.

Kim, Y. O. and A. Taniguchi, 1995: Excystment of the oligotrich ciliate Strombidium conicum. Aquat. Microb. Ecol., 9, 149-156, doi: 10.3354/ame009149. [Link]

Kim, Y. O. and A. Taniguchi, 1997: Seasonal variation of excystment pattern of the planktonic oligotrich ciliate Strombidium conicum. Mar. Biol., 128, 207-212, doi: 10.1007/s002270050084. [Link]

Kim, Y. O., T. Suzuki, and A. Taniguchi 2002: A new species in the genus Cyrtostrombidium (Ciliophora, Oligotrichia, Oligotrichida): Its morphology, seasonal cycle and resting stage. J. Eukaryot. Microbiol., 49, 338-343, doi: 10.1111/j.1550-7408.2002.tb00380.x. [Link]

Kim, Y. O., S. Ha, and A. Taniguchi, 2008: Morphology and in situ sedimentation of the cysts of a planktonic oligotrich ciliate, Strombidium capitatum. Aquat. Microb. Ecol., 53, 173-179, doi: 10.3354/ame01241. [Link]

Kremp, A., 2001: Effects of cyst resuspension on germination and seeding of two bloom-forming dinoflagellates in the Baltic Sea. Mar. Ecol. Prog. Ser., 216, 57-66, doi: 10.3354/meps216057. [Link]

Kremp, A. and A. S. Heiskanen, 1999: Sexuality and cyst formation of the spring-bloom dinoflagellate Scrippsiella hangoei in the coastal northern Baltic Sea. Mar. Biol., 134, 771-777, doi: 10.1007/s002270050594. [Link]

Leakey, R. J. G., P. H. Burkill, and M. A. Sleigh, 1992: Planktonic ciliates in Southampton Water: Abundance, biomass, production, and role in pelagic carbon flow. Mar. Biol., 114, 67-83.

Lennon, J. T. and S. E. Jones, 2011: Microbial seed banks: The ecological and evolutionary implications of dormancy. Nat.Rev.Microbiol., 9, 119-130, doi: 10.1038/ nrmicro2504. [Link]

Marcus, N. H., 1984: Recruitment of copepod nauplii into the plankton: Importance of diapause eggs and benthic processes. Mar. Ecol. Prog. Ser., 15, 47-54, doi: 10.3354/meps015047. [Link]

McManus, G. B., D. Xu, B. A. Costas, and L. A. Katz, 2010: Genetic identities of cryptic species in the Strombidium stylifer/apolatum/oculatum cluster, including a description of Strombidium rassoulzadegani n. sp.. J. Eukaryot.Microbiol.,57,369-378,doi: 10.1111/j.15507408.2010.00485.x. [Link]

Montagnes, D. J. S., D. Wilson, S. J. Brooks, C. Lowe, and M. Campey, 2002: Cyclical behaviour of the tide-pool ciliate Strombidium oculatum. Aquat. Microb. Ecol., 28, 55-68, doi: 10.3354/ame028055. [Link]

Müller, H., 1996: Encystment of the freshwater ciliate Pelagostrombidium fallax (Ciliophora, Oligotrichida) in laboratory culture. Aquat. Microb. Ecol., 11, 289-295, doi: 10.3354/ame011289. [Link]

Müller, H, and C. Wünsch, 1999: Seasonal dynamics of cyst formation of pelagic strombidiid ciliates in a deep prealpine lake. Aquat. Microb. Ecol., 17, 37-47, doi: 10.3354/ame017037. [Link]

Müller, H., P Stadler, and T. Weisse, 2002: Seasonal dynamics of cyst formation of strombidiid ciliates in alpine Lake Mondsee, Austria. Aquat. Microb. Ecol., 29, 181-188, doi: 10.3354/ame029181. [Link]

Nehring, S., 1996: Recruitment of planktonic dinoflagellates: Importance of benthic resting stages and resuspension events. Int. Revue Ges. Hydrobiol., 81, 513527, doi: 10.1002/iroh.19960810404. [Link]

Nielsen, T. G. and T. Kiørboe, 1994: Regulation of zooplankton biomass and production in a temperate, coastal ecosystem. 2. Ciliates. Limnol. Oceanogr., 39, 508519, doi: 10.4319/lo.1994.39.3.0508. [Link]

Ohman, M. D. and R. A. Snyder, 1991: Growth kinetics of the omnivorous oligotrich ciliate Strombidium sp.. Limnol. Oceanogr., 36, 922-935, doi: 10.4319/ lo.1991.36.5.0922. [Link]

Pitta, P., A. Giannakourou, and U. Christaki, 2001: Planktonic ciliates in the oligotrophic Mediterranean Sea: Longitudinal trends of standing stocks, distributions and analysis of food vacuole contents. Aquat. Microb. Ecol., 24, 297-311, doi: 10.3354/ame024297. [Link] 
Reid, P. C., 1987: Mass encystment of a planktonic oligotrich ciliate. Mar. Biol., 95, 221-230, doi: 10.1007/ BF00409009. [Link]

Reid, P. C. and A. W. G. John, 1978: Tintinnid cysts. J. Mar. Biol. Assoc. U.K., 58, 551-557.

Santschi, P.H., C.C.Hung, G. Schultz, N. Alvarado-Quiroz, L. Guo, J. Pinckney, and I. Walsh, 2003: Control of acid polysaccharide production and ${ }^{234} \mathrm{Th}$ and POC export fluxes by marine organisms. Geophys. Res. Lett., 30, doi: 10.1029/2002GL016046. [Link]

Sherr, E. B., F. Rassoulzadegan, and B. F. Sherr, 1989: Bacterivory by pelagic choreotrichous ciliates in coastal waters of the NW Mediterranean Sea. Mar.Ecol.Prog. Ser., 55, 235-240.

Stoecker, D. K., A. Taniguchi, and A. E. Michaels, 1989: Abundance of autotrophic, mixotrophic and heterotrophic planktonic ciliates in shelf and slope waters. Mar. Ecol.Prog. Ser., 50, 241-254, doi: 10.3354/ meps050241. [Link]

Stoecker D. K., D. J. Gifford, and M. Putt, 1994: Preservation of marine planktonic ciliates: Losses and cell shrinkage during fixation. Mar. Ecol. Prog. Ser., 110,
293-299, doi: 10.3354/meps110293. [Link]

Suzuki, T., N. Yamada, and A. Taniguchi, 1998: Standing crops of planktonic ciliates and nanoplankton in oceanic waters of the western Pacific. Aquat. Microb. Ecol., 14, 49-58, doi: 10.3354/ame014049. [Link]

Tsai, A. Y., G. C. Gong, K. P. Chiang, C. F. Chao, and H. R. Guo, 2011: Long-term (1998-2007) trends on the spatial distribution of heterotrophic ciliates in the East China Sea in summer: Effect of the Three Gorges Dam construction. J. Oceanogr., 67, 725-737, doi: 10.1007/ s10872-011-0069-5. [Link]

Verni, F. and G. Rosati, 2011: Resting cysts: A survival strategy in Protozoa Ciliophora. Ital. J.Zool., 78, 134145, doi: 10.1080/11250003.2011.560579. [Link]

Weisse, T., 2004: Meseres corlissi: A rare oligotrich ciliate adapted to warm water and temporary habitats. Aquat. Microb. Ecol., 37, 75-83, doi: 10.3354/ame037075. [Link]

Zinabu, G. M. and T. L. Bott, 2000: The effects of formalin and Lugol's iodine solution on protozoal cell volume. Limnologica, 30, 59-63, doi: 10.1016/S00759511(00)80044-4. [Link] 